\title{
NAKAZ BOŻY JAKO FORMA WOLNOŚCI
}

Niklas Luhmann

\section{$/ / / 1$.}

Chcąc na wstępie osiagnać porozumienie w kwestii tematu, rozsądnie będzie rozpoczać przypowieścią (Rumi 1925-1940: 185 i nn.). Pewien ogrodnik spostrzegł, że jakiś człowiek wspiął się na jedno z jego drzew i zjada owoce. Zaczął robić mu wyrzuty, lecz człowiek ów odparł: „Nie miałbym chęci jeść tych owoców ani nie wspiąłbym się na to drzewo bez woli Bożej. Wszystko to stało się z jej przyczyny, nie masz więc powodu, by czynić Bogu wymówki”. Usłyszawszy to, ogrodnik wziął „laskę Boga” i bił nią złodzieja tak długo, póki ów nie porzucił swej teologii i nie przyznał, że była to jego nieskrępowana decyzja. Uzupełniając i interpretując: po złych doświadczeniach z wolą strony zamiast do niej, odwołują się do rozróżnienia, a mianowicie do kodu prawa i niesprawiedliwości, który pozwolił w zróżnicowany sposób (wraz z rozwojem cywilizacji „z umiarem" = sprawiedliwie) warunkować zachowanie. W ten sposób powstała wolność jako możliwość wyboru jednej strony tego rozróżnienia. Tak najwyraźniej stało się z wiedzą i wolą Bożą. Można ten fakt zaakceptować. Jednak jeśli chodzi o refleksję nad tą akceptacją, czyli o teologię, pojawia się pytanie, jak można to zrozumieć, zinterpretować, pojać i oczyścić teoretycznie.

Dopiero na poziomie teorii refleksyjnej istnieją powody $-z$ perspektywy religioznawczej lub też socjologicznej - by obserwować czasowe uwarunkowanie teologicznych figur refleksji. Gdyby nawet można było przyjąć, że „ostatecznie” zawsze chodzi o to samo (ujmując to socjologicznie - o jedną i tę samą funkcję), mogłoby być tak, że ta funkcja, a przede wszystkim jej refleksja, przyjmie różne formy semantyczne w zależności od tego, w jakim społeczeństwie pragnie zdobyć wiarygodność. Już same pojęcia zawarte w tytule, jak „nakaz”, „Bóg”, „forma” czy „wolność", były z pewnością odmiennie rozumiane w różnych czasach i społeczeństwach, choćby przez to, że prawdopodobnie przeciwstawiano je całkowicie odmiennym pojęciom przeciwnym. Tak przedstawia się kwestia „nowoczesnej” teologii. 
Dzisiejsze społeczeństwo stoi w obliczu faktu, że jego forma zróżnicowania nie pozwala już na reprezentowanie jedności społeczeństwa w społeczeństwie. Nie istnieje ani odpowiednia elita (na przykład arystokracja czy monarcha), ani też centrum (na przykład miasta w przeciwieństwie do wsi), gdzie jedność całości mogłaby zostać przedstawiona w sposób zasadniczy i bezalternatywny. Nie istnieją również stanowiska, z których można by autorytatywnie obwieścić wiedzę, jak gdyby z nich i tylko z nich można było obserwować rzeczywistość i relacjonować ja innym. Jean Lyotard scharakteryzował niemożność całościowego przedstawienia jako condition post-moderne ${ }^{1}$ (Lyotard 1997). Jeśli zważyć na związek ze strukturami społecznymi, a szczególnie z formami zróżnicowania społeczeństwa, oczywiste jest dostrzeżenie osobliwego samodoświadczania nowoczesności, która u schyłku minionego stulecia odrzuciła wszystkie przejściowe semantyki i spostrzegła, co się rozwinęło.

W związku z tym na znaczeniu zyskały analizy z punktu widzenia teorii różnicy. Prawdopodobnie najcelniejszym przykładem jest lingwistyka Ferdynanda Saussure'a, innym byłaby filozofia Jacques'a Derridy. Nie jest przypadkiem, że dawne założenia co do bytu i podmiotu zostały ,zdekonstruowane”. Nie należy się jednak zbyt szybko przerażać. Prawdziwym przesłaniem jest to, że wszystkie ustalenia mają sens wyłącznie w kontekście rozróżnienia i dlatego za każdym razem trzeba odróżnić, od jakiego rozróżnienia się wychodzi. W terminologii Gottharda Günthera można powiedzieć: myślenie monokontekstualne jest zastępowane myśleniem polikontekstualnym (Günther 1979: 283-306).

Po dziś dzień teorie poznania wychodzą od aksjomatu niesprzeczności. To znaczy, że zmuszaja poznanie, gdziekolwiek natknie się ono w przedmiotach lub działaniach na cechy przeciwstawne, do ich usunięcia przez rearanżację zdań - czy to przez analizę, czy przez relatywizację. Doprowadziło to do ogromnych postępów poznawczych, a w odniesieniu do działania - do postępów w koncepcjach etycznych i racjonalistycznych. Z tego powodu aksjomat niesprzeczności zachowuje ważność jako rekurencyjnie ustabilizowany, a przynajmniej jako pragmatycznie niepodważalny. Z drugiej strony, w obiektach fizycznych istnieją dziś stany faktyczne, które nie poddają się takiemu postępowaniu i mogłoby być tak, że teoria poznania zostałaby zmuszona do zmiany swej orientacji, mianowicie na konieczność rozróżniania, która została wprowadzona jako nakaz i pojmuje wykorzystywane za każdym razem rozróżnienie jako

\footnotetext{
${ }^{1}$ fr. kondycja ponowoczesna [Wszystkie objaśnienia wyrazów obcych w tekście pochodzą od tłumacza].
} 
„ślepa plamkę” określeń, które zostały przez nią umożliwione; jako ślepa plamkę lub też jako niedostrzegalny paradoks, który nie powinien ukazać, że wychodzi się od jedności tego, co zróżnicowane.

Najbardziej radykalną formę zwrotu ku myśleniu z perspektywy teorii różnicy można odnaleźć u George’a Spencera Browna, który starał się na jej podstawie ponownie sformułować tradycyjna arytmetykę i uwzględniwszy czas, zmienić ją w równie sprawny program operacyjny, by dzięki temu móc zająć się paradoksami (Spencer Brown 1979). Nie odnosząc się do samej logiki, chcemy wykorzystać ten pomysł.

Przed każdym określeniem pozytywności (zdolność do nawiązywania) i negatywności (zdolność do refleksji) należy coś rozróżnić i określić. Spencer Brown rozpocząl nakazem: draw a distinction! ${ }^{2}$. O nic innego nie ma się teraz co martwić3. Każde postępowanie rozpoczyna tryb nakazujący, jako wykonanie nakazu. Można zatem zadać pytanie: Kto wydaje nakaz? ${ }^{4}$ Lecz czy człowiek może o to pytać? Można nie podjąć tego pytania lub też zastapić je warunkiem: jeśli chcesz rozwinać rachunek form, musisz rozpoczać od rozróżnienia; każdy, kto tego pragnie, musi w ten sposób określać swoje działanie. W tej mierze działa kalkulacja z autorem, który pozostał anonimowy. Jednak taki warunek już zakłada, że człowiek - czy tego chce, czy nie - może odróżniać. To zaś ponownie prowadzi do pytania: kto zmusza mnie do rozróżniania?

Kiedy człowiek pyta w taki sposób i poszukuje autora nakazu, to już odróżnił nakaz, a w pytaniu o autora przyjął rozróżnienie. Rozpoczą już zatem i musi zadać sobie pytanie: dlaczego tak, a nie inaczej? Logika Spencera Browna wymaga nierozróżnialnego rozróżnienia, jako początku jakiegokolwiek rozróżnienia, które nie jest określone przez swoją różnicę w stosunku do innych odróżnień. W innym razie nie da się naprawdę rozpocząć postępowania. Dopiero kiedy określi się rozróżnienie i przeprowadzi się linię graniczna, może ono ze swojej strony zostać rozróżnione (każda racjonalizacja to postracjonalizacja.) Kiedy owo draw a distinction! zostało powiedziane lub napisane, cisza jest już naruszona, biel papieru zniszczona i człowiek zastanawia się potem: dlaczego można to zrobić, dlaczego trzeba?

\footnotetext{
2 ang. przeprowadź rozróżnienie.

${ }^{3}$ Należy jeszcze przezornie zauważyć, że to, co pozytywne i to, co negatywne będzie traktowane jako rezultat (a nie jako warunek wstępny) rozróżniania - jako powtórzenie (law of condensation) lub przejście z jednej na drugą stronę (law of cancellation) rozróżnienia.

${ }^{4}$ Pytanie to zadawał na przykład R. Glanville (1979: 70-74. Przekład niemiecki: Glanville 1998: 149-166; 150 i n.).
} 


\section{/// 3.}

Teologia może teraz czuć się wywołana, by podjąć ciężar odpowiedzi. Autorem nakazu, który nie jest w nim nazwany i nie może zostać odróżniony, mógłby być Bóg. Wbrew temu, co często przyjmowano, świat widzialny nie zostałby stworzony dla podziwiania i poznania Boga, lecz jako sposobność do rozróżnień i określeń. Dlatego stwarzanie dokonuje się poprzez słowo i nadaje rzeczom nazwy, by uczynić je odróżnialnymi. Wiążący się z tym paradoks nieodróżnialnego rozróżnienia i początku bez początku okazałby się od dawna znanym problemem, którym zajmowano się w różny sposób odkąd powstało pismo. Zaczyna się on od logosu, który nie byłby ani potencja, ani rozsądkiem, ani też słowem jako słowem, lecz różnica poczyniona, gdy jakieś słowo zostaje wypowiedziane i okazuje się zdolne do łączenia ${ }^{5}$. Wolność zostałaby stworzona poprzez rozkaz: „Bądź posłuszny!” i przez daną tym samym możliwość nieposłuszeństwa oraz zapoznania się z jego konsekwencjami. Historię o złodzieju i ogrodniku można teraz zinterpretować w następujący sposób. Albo Bóg powiedział: „weź owoc”, albo „weź laskę”. Jego nakaz brzmi: „Odróżniajcie!” Naturalnie, złodziej odróżnił owoc, a ogrodnik laskę. W innym wypadku żaden z nich nie mógłby ich chwycić. Jednak kiedy odróżniają oni w odmienny sposób (i tylko wtedy), pojawia się odróżnialne rozróżnienie, stanowiące sposobność do rozwinięcia wyspecjalizowanego odróżnienia, jak na przykład prawa i niesprawiedliwości z całym aparatem norm i wykroczeń, reguł i wyjątków.

Czy Bóg może zostać zredukowany do przykazania rozróżniania, a więc do tworzenia fatalizmu, polegającego na tym, że człowiek nie umie spostrzec, kiedy nie może rozróżniać i że również ślepe działanie czyni różnicę dla tego, kto je obserwuje? W ten sposób jako rozróżnienie zaistniałby ograniczający związek wolności i związania, wolności wyboru jednej lub drugiej strony i związania rozróżnieniem, które człowiek bierze za podstawę wyboru. Ponadto tym samym założono, że wszystko, co czyni człowiek, pozostaje odróżnialne, a zatem obserwowalne. W terminologii Spencera Browna brzmi to następująco: stworzenie świata jest naruszeniem unmarked state ${ }^{6}$, które następuje po tym, co nowe, kiedy człowiek rozpoczyna. Dawny związek wolności i konieczności nie byłby niczym innym jak zrozumieniem, że wskazywanie i odróżnianie (indication and distinction) są składowymi jednej, jedynej operacji i mogą zostać rozróżnione (!) tylko przez obserwatora.

\footnotetext{
${ }^{5}$ Również tutaj można powrócić do Lyotarda, a szczególnie do sposobu, w jaki widzi on phrase i enchaînement jako proces, który wytwarza różnicę i nie mo że ç̧ynić inaczej. Zob. (Lyotard 1983).

${ }^{6}$ ang. stan nieoznaczony.
} 
Dla tego, który może i jednocześnie musi odróżniać, widzialne pozostaje zawsze tylko za każdym razem stosowane przez niego rozróżnienie. Rodzaj jego świata zawsze jest konstruowany wyłącznie jako identyczność w różnicy, czy to jako paradoksalna formuła, oznaczająca, że jedność dobrego i złego jest dobra (przykładowo w myśl teorii transcendentaliów), czy też w sensie kontinuum równań cząstkowych fizyki kwantowej, które oznacza, że istnieje obliczenie, za pomoca którego obserwator może obliczyć wynik obliczeń innego obserwatora ${ }^{7}$.

Ponieważ rozróżnienie zaznacza granicę, wskutek czego można przejść $z$ jednej strony na druga tylko przez jej przekroczenie, stanowi ono for $\mathrm{m}$ ę (nie istnieje żadna inna forma formy). Ta terminologia pozwala dołączyć dawne rozważania dotyczące pojęcia Boga. Sam Bóg, o ile nadaje formę, jest formą i brakiem formy, jest również tym, co unika każdej formy, i znów tym nie jest. Jan Szkot Eriugena sformułował to następująco: „Forma est, forma non est, informitas est, informitas non est" (Eriugena 1978 [przekład polski Eriugena 2009]). Postęp leży w interpretacji tego, co oznacza for m ę, w zrozumieniu, że nie stanowi ona specyfikacji bytu, lecz rozróżnienie. Nie trzeba zatem posuwać się daleko, by zredukować Boga do przykazania rozróżniania czy mówić, że odróżnianie stanowi egzystencję podmiotu, który rozróżnia (Glanville 1998: 152). Odniesienie do Boga można raczej dostrzec w tym, że każde odróżnianie implikuje odróżnienie rozróżnienia bez możliwości upewnienia się co do założonego rozróżnienia. Zgodnie z tym Bóg byłby w tym, co w sposób nieunikniony obecne, a co Francisco Varela nazwał selfindication ${ }^{8}$ rozróżnienia (Varela 1975: 5-24).

Nie daje to jednak zbyt wiele w odniesieniu do pojęcia Boga, a przede wszystkim nie przyczynia się do wyjaśnienia Jego stosunku do siebie. Konsekwencja tej interpretacji jest w pełni znana teologom, widać to na przykład w pismach Eriugeny. Bóg nie może sam siebie rozpoznać, ponieważ nie może się sam od niczego odróżnić. Jest również dla samego siebie niedefiniowalny, niepodzielny i nieokreślalny ${ }^{9}$. Z tego wynika, że ani teologia pozytywna, ani negatywna nie jest zadowalająca, bowiem skąd wzięłoby się rozróżnienie? Tylko konieczność odróżniania jest sama w sobie zrozumiała, a z tego powodu Bóg jest zrozumiały wyłącznie przez nakaz: „Odróżniaj!”.

\footnotetext{
${ }^{7}$ Nie powinno nas zwieść, że fizycy mówią o indeterminizmie czy determinizmie. Jest nazbyt jasne, że to, co mają oni na myśli, nie może b y ć nieokreślone, ponieważ negatywność istnieje zawsze jedynie w mowie jako sposób operacji myślenia lub komunikacji.

${ }^{8}$ ang. wskazywanie na siebie.

9 „Quomodo igitur divina natura se ipsam potest intelligere quid sit cum nihil sit?” oraz „Deus itaque nescit quid est quia non est quid, incomprehensibilis quippe in aliquo et sibi ipsi et omni intellectui" (Eriugena 1972: 142).
} 
Jeśli za pomocą tego wszystkiego nie wyjaśniliśmy stosunku Boga do siebie, to jednak powiodło się objaśnienie (prawie można by powiedzieć: „unowocześnienie”) Jego stosunku do świata. Bóg wydał - jak musieliby powiedzieć teologowie - nakaz: „Odróżniaj!” i umożliwił nim istnienie świata, jednak On sam pozostał w sferze tego, co nieodróżnialne, na świecie może być obecny jedynie jako ślepa plamka każdej praktyki rozróżniania, nieodróżnialność jedności rozróżnienia stosowanego za każdym razem. Nie można pojmować świata jako zbioru materialnych i niematerialnych rzeczy, lecz jako kondensat praktyki rozróżniania, która jako praktyka, chociaż nie w momencie swojej realizacji, obserwuje się i określa, pozwalając na rozróżnianie i opisywanie.

\section{$/ / / 4$.}

Visio Dei stanowi obietnicę doświadczenia świętości. Jednak teolodzy (większość czy też wielu z nich) obserwują Boga już za swojego życia, tak jak gdyby wiedzieli, wedle jakich kryteriów On ocenia (ostatnio najwyraźniej wedle ekologicznych). Kiedy wyszło na jaw stosowanie hormonów u cielaków, teologowie zaraz ogłosili, że Bóg nie stworzył ich przecież po to, by były tuczone w przepełnionych oborach. Choć będzie to coraz trudniejsze, powinni oni nadal podejmować starania, by jednak uczynić ludzi podstawą dla swoich działań - a jeśli nie wszystkich, to przynajmniej powiązanych z Kościołem. Rozróżnienia nie są obojętne, lecz przedkładane już z pewnym opowiedzeniem się. Należy jednak rozróżnić między wyborem rozróżnienia i opowiedzeniem się w jego ramach za którąś opcją w ramach tego rozróżnienia - za obydwa człowiek powinien wziąć odpowiedzialność.

Nawet gdy teolodzy odrzucaja rozróżnienie na sacrum i profanum (przypuszczalnie dlatego, że pozostaje ono związane z rytualizacją i tabuizacja), nierzadko sprawiają wrażenie, jak gdyby istniały szczególne czasy i miejsca, w których Bóg jest bliżej ludzi niż w pozostałych. W szczególny sposób odnosi się to do szabatu, niedzieli, świąt kościelnych i życzenia, by w wyznaczonym czasie nawiedzać budynki, powszechnie określane mianem kościołów. W przykazaniu, by święcić szabat-niedzielę, czyli wyłączać je, być może chodzi tylko o przeprowadzenie rozróżnienia, gdyż w ten sposób można doświadczyć Boga po obu stronach rozróżnienia i niejako bez preferencji.

Dystans w stosunku do tradycyjnych założeń myślowych, ukazujący się w powyższych rozważaniach, najlepiej uobecnia się przez sprawdzanie ich w szczególnie ważnych rozróżnieniach tradycji. Nakaz: „Rozróżniaj!” nie narzuca żadnego konkretnego rozróżnienia, lecz jedynie samo rozróżnianie. Wymaga ono dostatecznej określoności, tak że można ustalić, czy stanowi się punkt wyjścia dla dalszych operacji po jednej lub po drugiej stronie, a także 
kiedy przechodzi z jednej na druga (Spencer Brown: crossing). Porządek, biorący się z rozróżnienia, wynika z sekwencji działań pozwalających się ze sobą powiązać, a nie opiera się jedynie na treści samego rozróżnienia. Innymi słowy: rozróżnienie, od którego wychodzi człowiek, jest albo zasada, albo podstawą dla porządku ${ }^{10}$. Zgodnie $z$ tym, każde określone rozróżnienie stanowi już pewien wybór, jest już kontyngentne, a zatem także w inny sposób możliwe. Żadna strona nie jest narzucona nakazem lub wyróżniona jako słuszna (istotna, naturalna, świątobliwa itd.). W większym stopniu zależy to od tego, co się w ten sposób rozpocznie i dokąd dotrze. Obowiązuje to również w stosunku do rozróżnień, które na pierwszy rzut oka wydają się nieuniknione i nieodparte.

Rozróżnienie na byt i niebyt nie jest konieczne ${ }^{11}$. Prowadzi ono ku ontologii (Luhmann 1990: 15-30), odłącza niebyt od bytu, rezerwując go tym samym dla obserwatora, który orientuje się za pomocą logiki dwuwartościowej tylko z jedną wartością desygnowaną i z jedną wartością refleksyjną, służącą do kontroli błędów i który ostatecznie marnieje do [formy] pozaświatowego podmiotu albo wręcz do niczego. Niewątpliwie jest to schemat skuteczny, lecz w obliczu rozmaitych (w dużej mierze logicznych) trudności należałoby rozważyć czy nakaz: „Rozróżniaj” interpretować jako: zacænij jak Parmenides (zgodnie z Bożym nakazem, a nie jak frywolny, eksperymentujący sofista) od roz̧różnienia bytu i niebytu.

Niekonieczne jest także rozróżnienie dobrego i niedobrego czy dobrego i złego. Gdy ktoś wybiera to rozróżnienie (a więc je jabłko z drzewa poznania), dochodzi do moralności. W przeciwieństwie do ontologii, było to zabronione. Zakaz musial jednak najpierw zostać ustanowiony jako nakaz odróżniania. Rozróżnienie przynosi ze soba podobne zadanie dla Boga oraz diabła, ma mianowicie umożliwić człowiekowi rozróżnianie; anioł podjął się go jako diabeł, by oddać do dyspozycji możliwość rozróżnienia dobrego i złego w określeniach ${ }^{12}$. Wybór tego rozróżnienia

\footnotetext{
${ }^{10}$ Patrząc wstecz, łatwo jest rozpoznać metaforykę jedności, która stanowi podstawę takich elementarnych pojęć, jak zasada czy podstawa. I także to, że trzeba rozróżniać metaphérein i diaphérein.

${ }^{11}$ Spojrzenie na taoizm uczy, że to rozróżnienie nie jest konieczne religijnie. Por. na przykład Smullyan (1977). To, czy pojęcie Boga zmusza do postawienia pytania o byt i niebyt i do potwierdzenia za pomocą tego pytania wiary w Boga, zależy niewątpliwie od ujęcia tego pojęcia.

${ }^{12}$ Czasem przedstawia się to stanowisko jako skrajny przypadek miłości do Boga - jak w przypadku diabła Iblisa. W każdym razie, ów diabeł zna jedność operacji rozróżniania i wie, że jego miłość do Boga cierpi z powodu odejścia. W każdym razie podobnie zakłada interpretacja J. Rumiego (Rumi 1926: np. 360). „Although these twain - good and evil - are different, yet these twain are (engaged) in one work". Analogicznie, Bóg nie mógł przyjąć skruchy Adama, ponieważ sam zmusił go do rozróżniania: „After his repentence, He (God) said to him, «O Adam, did not I create in thee that sin and (those) tribulations? Was it not My foreordainment and destiny? How didst thou conceal that at the time of excusing thyself?»" (Rumi 1926: 82). Wydaje się oczywiste, że ta nieprzejrzystość powstaje przez podstęp diabła. Jednak jak Bóg mógł to zarzucić Adamowi? Por. Awn 1983, szczególnie rozdział III. Na temat żydowskiego i chrześcijańskiego kontekstu: Jung 1925, Zwemer 1937.
} 
jest grzechem (jeśli nie jako wina, to jako habitus). Jedność dobrego i złego jest zatem równiez - na przekór długiej tradycji - nie dobra, lecz zła ${ }^{13}$ i jeśli się wybiera to rozróżnienie, jedyną rzecza, jakiej może się nauczyć, jest cierpliwość wobec innych ${ }^{14}$. Ograniczenie do moralności obciążało religię wystarczająco długo (Luhmann 1989), prowadząc aż do nerwic lękowych w odniesieniu do zbawienia czy potępienia duszy oraz silnie wiążąc religię o integracyjnych funkcjach moralności z wykluczeniem potępianych. Powstająca wczesnonowożytna teoria państwa wykorzystywała religię jako instancję moralną; dziś teolodzy są powoływani do komisji etycznych, gdy chodzi o zadania państwa. Kiedy w ten sposób moralnie kodować religię, jej osobliwość musi zaznaczyć się w formie ocalającego ostrzeżenia dla grzeszników, a zatem jako akt łaski. W konsekwencji każdy musi być grzesznikiem, żeby wszyscy mogli mieć udział w łasce. Rozstrzygnięcia co do form teologii zależą zatem stosunkowo bezpośrednio od wyjściowego wyboru jednego z wielu możliwych rozróżnień. Dziś nie jest to tak przekonujące, dlaczego wprowadzanie ładu musi posługiwać się taką sekwencją.

Jeśli raz wybrano ontologię i moralność jako podstawowe rozróżnienia w pytaniach kognitywnych lub normatywnych, ma to wpływ na pytanie o jedność obecnego rozróżnienia, zgodnie z rozumieniem „i” między bytem i niebytem oraz dobrym i złym. Nacisk jest kładziony jednostronnie na stronę pozytywną. Zamiast szukać jedności w różnicy, łączy się pozytywne strony różnych rozróżnień w jedność: ens et verum et bonum convertuntur. Kto nadal obserwuje tę wyjątkowa jedność, czyli pragnie odróżniać, stanie się diabłem. Obserwacja transcendentalnej jedności wymaga granicy, która wyłączy obserwującego. $\mathrm{Na}$ uwagę zasługuje osobliwie wysoka pozycja obserwatora, pochodzi on zawsze z najwyższej arystokracji i jest związany wytycznymi tego, co chce obserwować. Jest najintensywniej żyjącym ${ }^{15}$. Staje się ofiarą tego, co obserwatorowi wydaje się paradoksem (w islamie jako Iblis, ofiara paradoksalnego nakazu Allacha), a z tego powodu także obserwatorem, który nie może określić swojej własnej pozycji. Abstrahując od wpływów prymitywnej demonologii, diabeł jest tragiczną postacią narzucenia dominującego rozróżnienia, nie bez melancholii wypełniająca zadanie połowu dusz oraz program, który można nazwać sprawiedliwością

\footnotetext{
${ }^{13}$ Należy podkreślić, że nie oznacza to, że dobro nie jest dobre, a zło złe. Chodzi tu o jedność tego rozróżnienia, a więc o rozróżnienie tego rozróżnienia od innych rozróżnień. Chodzi o moralizowanie.

${ }^{14}$ Podobnie autor z czasów szesnastowiecznego zamętu religijnego - Marconville (1564) (broniąc Ewy).

${ }^{15}$ P. Awn (1983: 124) określił go mianem ,perfekcyjnego monoteisty”.
} 
dla grzeszników ${ }^{16}$. Być może Bóg ceni obserwatora, który nie powtarza bezmyślnie, lecz przynajmniej próbuje podejść do granicy i rzucić ponad nią okiem ${ }^{17}$. Bóg wynagradza mu to wiecznym wygnaniem - permanencja jego pozycji jako obserwatora.

W końcu, istnieje również rozróżnienie, za pomocą którego określa się akt czystej miłości - przebacz grzesznikom albo wymaż mię natychmiast z Twej księgi (Wj 32,32) - jako jedno z wielu roszczeń przelicytowujących diabła ${ }^{18}$. Jeśli gra będzie rozgrywana na płaszczyźnie ontologiczno-moralnej, w rachubę wchodzą ekstremalne pozycje tego rodzaju. Jeśli nie będzie, to wówczas nie ma o nich mowy. Ontologicznie-moralna gra zna tylko jedną skłonność, za każdym razem prawdziwą ${ }^{19}$.

Co jednak pozostaje do obserwowania? W Listach ₹ Ziemi autorstwa Marka Twaina Bóg ogłosił (ku przerażeniu Szatana) prawo natury jako automatic law $w^{20}$. Szatan, Gabriel i Michał komentuja jako obserwatorzy (do pewnego stopnia z loży szyderców): „Byliśmy świadkami wspaniałego zjawiska, co do tego oczywiście się zgadzamy. Natomiast znaczenie tego zjawiska - jeśli ono w ogóle istnieje - osobiście nas nie dotyczy. Możemy na ten temat mieć tyle opinii, ile nam się podoba i na tym koniec. Nie mamy głosu". Po dokonaniu stworzenia Bogu pozostaje jedynie możliwość poprawy, to znaczy stworzenia dalszego automatyzmu z wbudowaną moralną złożonościa, człowieka - eksperymentu, który wedle ziemskich obserwacji Szatana okazuje się wattpliwy (Twain 1962: 3 [polskie wydanie Twain 1966: 20]).

\section{/// 5.}

Niekiedy filozoficzna teologia dociera do granic swojej tradycji i podnosi kwestię przekroczenia wszystkich rozróżnień. W większym stopniu, niż tradycyjna teoria poznania, teologia była w stanie odnieść wszystko, co

\footnotetext{
${ }^{16}$ Prawny charakter sposobu postępowania diabła rzuca się w oczy przede wszystkim w tekstach średniowiecznych (zob. Russel 1984: 80 i nn., 104 i nn.; Spangenberg 1987: 233 i nn). Analogicznie, wczesnonowożytna literatura sama niekiedy charakteryzuje zbawienie jako zbawienie od prawa - a zatem od tego rozróżnienia. „Delivering us from [...] the Severity, Justice and Curse of the Law”, jak stwierdza Reynolds (1640).

${ }^{17}$ „Mais moi, ajoutait-il, je suis le dieu de ceux qui me résistent en tant que je suis, et qui me désirent en tant que je ne suis pas", jak stwierdził P. Valéry (Valéry 1960: 440).

${ }^{18}$ Utarta interpretacja teologiczna tego stanowiska jako propozycji ofiary pokutnej osoby niewinnej, zmierzającej do uwielbienia ofiarności, przysłania tym samym prowokację Boga, która leży w tym żądaniu. Zob. interpretację jako propozycje pokuty Gese (1977: 87 i nn.); Janowski (1982: 142 i nn). (To wskazanie zawdzięczam M.Welkerowi).

${ }^{19}$ Raz jeszcze zacytujmy Rumiego na temat Iblisa: „Since there was no play but this on His board, and He said «Play», what more can I do? I played the one play (move) that there was, and cast myself into woe. Even in woe I am tasting His delights: I am mated by Him, mated by Him, mated by Him!" (Rumi 1926: 358).

${ }^{20}$ ang. prawo automatyczne.
} 
jest i co nie jest, do nadania nazwy, a zatem do rozróżnienia (differentia lub distinctio), ponieważ posiada ona tę transcendentującą zasadę w pojęciu Boga. Szczególnie dobitnie ukaże się to na przykładzie Mikołaja z Kuzy.

Pojęcie Boga wedle Kuzańczyka znajduje się poza wszystkimi rozróżnieniami, także poza rozróżnieniem samego Boga oraz rozróżnieniem na rozróżnione i nierozróżnione. Bóg jest według niego ante omnia quae differunt (Mikołaj z Kuzy, De venatione sapientie 1964a: 56) ${ }^{21}$. W Bogu nie da się pojmować rozróżnienia i nierozróżnienia jako sprzeczności: distinctio est indistinctio $^{22}$. W rozróżnieniu każda strona służy jako różna od tej drugiej. Jest inna niż ta druga, co oznacza rozróżnienie. Przeciwnie, samo rozróżnienie należy zatem rozumieć jako nie-inne tego, co rozróżnione. O ile rozróżnione ma udział w rozróżnieniu, nie jest ono różne od wszystkiego innego. Nonaliud jest dla Kuzańczyka absolutem ${ }^{23}$.

W rozróżnieniu leży granica między jedną a drugą stroną. By między nimi przejść, potrzebny jest czas. Logika Spencera Browna jest w tym sensie logiką niestatyczna, włączającą czas. Rozróżnienie samo w sobie jest dwustronną forma, równoczesnością rozróżnionego. Tylko wtedy, gdy się chce znów samodzielnie rozróżniać i określać, musi powrócić do czasu bez możliwości uniknięcia jednoczesności wykorzystanego teraz rozróżnienia dla rozróżnień.

Wraz z przekroczeniem rozróżnienia bytu i niebytu Mikołaj Kuzańczyk przekroczył również podstawę ontologii i przyporządkowana jej logikę quodliber est vel non est ${ }^{24}$. Rezerwat teologii jest mocno oparty na granicach różnicy, również jeśli można ją rozpoznać jedynie jako granice różnicy (w szczególności jako granice wzrostu i zmniejszania). W docta ignorantia intelekt porzuca posiadająca wiedzę, ale nie prowadząca do celu (ograniczona) irytację i w ten sposób zachęca się do chwalenia Boga.

Teologia pozostaje jednak związana swymi przesłankami. Dla Kuzańczyka działanie Boga jest darem bytu, a nie na przykład konstytutywnym nakazem: „Rozróżniaj!”. Z tego powodu nie można opisać Boga

\footnotetext{
${ }^{21}$ W wyjaśnieniu stwierdza, że: „On jest przed każdą różnicą, przed różnicą między faktycznością i możliwościa, możliwością istnienia i możliwością działania, światła i mroku, również przed różnica bytu i niebytu, czegoś i niczego oraz przed różnicą między brakiem różnicy a różnica, zgodnością i niezgodnością itd.”. Czy w tym ,itd.” ukrywa się różnica między bonum a malum?

${ }^{22}$ W kontekście doktryny o Trójcy Świętej - por. De docta ignorantia I, XIX (Mikołaj z Kuzy 1964b: 260) [przekład polski: Mikołaj z Kuzy 1997].

${ }^{23}$ Zob. De non-aliud (Mikołaj z Kuzy 1966: 433-465).

${ }^{24}$ Por. Apologia Doctae Ignorantiae (Mikołaj z Kuzy 1966: 546). Zob. także: De docta ignorantia I, VI (Mikołaj z Kuzy 1964: 212): „maxime igitur verum est ipsum maximum simpliciter esse vel non esse, vel esse et non esse, vel nec esse nec non esse; et plura nec dici nec cognitari possunt". Konsekwencja jest oczywiście to, że teologia nie jest możliwa w znaczeniu normalnego, logicznie pewnego poznania, lecz istnieje jedynie w docta ignorantia, to znaczy w pełnym zrozumienia wglądzie, że (i dlaczego) nie jest to możliwe.
} 
jako bytu w opozycji do niebytu ${ }^{25}$. Przejście od tego, co nierozróżnione, do tego, co rozróżnione (czyli od nieokreślonej do określonej złożoności), a tym samym od complicatio i explicatio do jedności różnicy, jest określane mianem emanacji lub stworzenia. To, co nierozróżnione, jest interpretowane jako jedność zawierająca się w każdym rozróżnieniu; właśnie ona, najpierw umożliwiając rozróżnianie, zostaje zdemaskowana jako trójjedyny Stwórca. Konsekwencje ujawniają się w przednowożytnym podejściu do świata. Z tego, co nierozróżnione, wywodzi się to, co rozróżnione w określonej, pięknej, harmonijnej, muzyczno-matematycznej formie. Tylko w ramach ustanowionej formy może ono ulegać zmianom czy też - przez jej opuszczenie - przechodzić w inną. Świat działa należycie, dlatego jego bonitas ${ }^{26}$ jest zrozumiała sama przez się. Został on dobrze (a nie źle!) stworzony i tylko diabeł może w to wattpić.

Stworzony świat określa się jako contractio, jako uniwersum rzeczy a nie coś, co samo z siebie rozwinęło się dzięki wyjściowemu poleceniu: rozróżniaj dobro i zło (wedle obserwatora). Kuzańczyk przypuszczalnie zauważył, że możliwości - w tym możliwości rozróżniania - są możliwe wyłącznie w świecie będącym przedmiotem umowy (co później upoważniło Kanta do pytania o warunki możliwości) oraz że człowiek musi odróżniać możliwości rozróżniania od nierozróżnialności, stanowiącej ich podsta$w_{e}^{27}$. Dla Mikołaja z Kuzy ostateczna podstawa wszystkich rozróżnień jest jedna, podczas gdy istnieje wiele zależnych od niej możliwości rozróżniania.

Nie dostrzeżono jednak, że można traktować jako jedność ekstremalne strony rozróżnienia o tyle, o ile one się same nie pozwolą rozróżnić. Rozróżnianie napotyka tutaj na własne paradoksy, postuluje bowiem początek i koniec rozróżniania jako różnicę. Lecz raz jeszcze: czy coś jest jednościa, jeśli jest paradoksem? Czy może nie pozostaje żadna różnorodność o tyle, o ile zawsze się musi pytać, wedle jakich rozróżnień (inaczej: dla jakiego obserwatora) jest to paradoks. Logika George'a Spencera Browna poszłaby w tym miejscu inną drogą niż teologia, szczególnie drogą złożoności budującej się z czasu, droga trzeciej wartości self-indication $n^{28}$ i re-entry ${ }^{29}$, ponownego wkroczenia rozróżnienia w to, co zostało przez nie zróżnicowane; prowadziłaby do tego, że każde rozróżnianie jest działaniem obserwatora $^{30}$. Nie daje to więcej, niż „postmodernistyczna” figura obserwatora, który

\footnotetext{
${ }^{25}$ Zob. Apologia Doctae Ignorantiae (Mikołaj z Kuzy 1966: 536): „dat omne esse” oraz „Deum nemquam concipi debere habere esse".

${ }^{26}$ łac. dobroć.

${ }^{27}$ Zob. passusy o rzeczywistości (actus) i możliwości (potentia) w De docta ignorantia II, VII (Mikołaj z Kuzy 1964: 361 i nn.). Tylko dla Boga możliwość jest rzeczywistością (possest).

28 ang. samowskazanie.

${ }^{29}$ ang. ponowne wkroczenie.

${ }^{30}$ Por. ważny w tym kontekście tekst: R. Glanville (1981: 638-641).
} 
ze zmienianymi za każdym razem rozróżnieniami obserwuje, co obserwują inni obserwatorzy, a czego nie moga obserwować. Taka odpowiedź nie jest religijnie satysfakcjonująca. Z drugiej strony teologiczna interpretacja religii nie może powrócić do owego średniowiecznego porządku obserwowania $($ definierens $=$ placierens $), \mathrm{w}$ którym zakładano rozróżnienie wyższych oraz niższych bytów, przy czym wyłącznie wyższe mogły definiować niższe ${ }^{31}$.

\section{/// 6.}

Pozostawmy teraz teologii jej własne troski i skierujmy się ku innym możliwościom wyjaśnienia pochodzenia rozróżniania - ku teorii René Girarda ${ }^{32}$. Jej wyjątkowość polega na tym, że nie zakłada po prostu początkowego stanu nierozróżnionego (unmarked state), lecz ze swojej strony próbuje go wyjaśnić jako indifférentiation primordiale (Girard 1982: 48). Powstaje ona dzięki naśladowaniu umożliwiającym pożądanie. Ewentualne różnice zacierają się przez to, że poprzez swoje pożądanie doprowadza się innego do pożądania tej samej rzeczy. W ten sposób powstaje mimetyczna rywalizacja, która włączona w porządek poprzez przemoc (violence), musi zostać zmieniona w rozróżnienia. Każdy porządek jest niejako już odwyróżnicowaniem. Wszystkie kryzysy stanowią naprawę indifférentiation primordiale. Każde ustawodawstwo jest grzechem (różnica), wymaga zatem ofiary: ofiary ustawodawcy.

To, co można zrozumieć jako mechanizm późnofreudowski, a w każdym razie antropologiczny, okazuje się w późniejszych pracach Girarda w coraz większym stopniu automatyzmem zamkniętego, samoodnoszącego się systemu. Każda biologicznie nadana różnica musi zostać zniesiona, musi stać się indyferentna, by możliwy był specyficznie społeczny porządek. Istnieje zatem jedynie społecznie wzbudzone i społecznie uwarunkowane pożądanie. Społeczeństwo wprawdzie nie uchyla swoich podstaw biologicznych, ale zaczyna samodzielnie fundować swój automatyzm.

W najstarszej mitologii przedstawiano to zjawisko jako kolektywny mord i obwiniano o niego przede wszystkim bogów ${ }^{33}$. Mord unicestwiał życie i tym samym symbolizował wyłonienie się innego porządku. Figura ta została stopniowo ucywilizowana wraz z rozwojem mitów (rozwojem społeczeństwa) i zharmonizowana z moralna jakością bogów - Boga jako

\footnotetext{
${ }^{31}$ Na przykład Jan Szkot Eriugena (1978: 132 i nn.), wraz z rozróżnieniem, że anioł i człowiek wprawdzie mogą odróżnić, ż e istnieją, ale nie ja ko co istnieja (,nulla natura sive rationalis sive intellectualis est quae ignoret se esse quamvis nesciat quid sit”, Eriugena 1978: 144).

32 Zob. przede wszystkim: Girard (1972 [przekład polski Girard 1993]), Girard (1978 [fragment w przekładzie polskim: Girard 1983]), Girard (1982 [przekład polski Girard 1987, 1991]).

${ }^{33}$ Girard broni wyłącznego roszczenia tej wersji. Należałoby jednak przyznać, że można by dodać do niej ekwiwalenty funkcjonalne (przykładowo w mitologiach płodzenia), które mniej drastycznie symbolizują porządek nadany biologicznie.
} 
symbolu dobra. Społeczeństwu w coraz większym stopniu przyznawano wyjaśnienie powstania różnic, jednocześnie ludzie przynajmniej współuczestniczyli w grzechu pierworodnym (wedle Miltona - będąc jednocześnie prawie niewinni) i zamordowaniu ofiary. Tymczasowy punkt końcowy buduje chrześcijański mit samobójstwa Boga, w którym sprawca i ofiara zbiegają się w jedno; tylko jeszcze Judasz i inni Żydzi dźwigają winę ${ }^{34}$. To, że dla początku rozróżniania konieczny jest mord, można zapomnieć dopiero na końcu. Przedmoralna jedność dobrodziejstwa i mordu, świętego i przeklętego, odnalazła formę, która jest zgodna ze społecznym odróżnieniem dobrego od złego. Trzeba jedynie pamiętać, że się nie może wiedzieć w sposób pewny, wedle jakich kryteriów (jeśli w ogóle wedle kryteriów, czyli wedle rozróżnień) będzie osądzał Sędzia Świata.

Wychodząc poza Girarda, samą teologię można teraz zinterpretować jako konflikt naśladowania. Jej wysiłki kierowane są na błogosławieństwo (beatitudo), ma ona nadzieję, że odnajdzie ja w visio Dei, czyli obserwacji Boga, tradycyjnie rozumiejąc obserwację jako assimilatio. Jak w przypadku każdego pożądania, musi istnieć pewien pierwowzór, który człowiek będzie naśladował. Tym wzorem jest anioł, który jako pierwszy tego spróbował. Prawdą jest, że ta próba, jak każda obserwacja, zakłada delimitację. Musiałoby to obowiązywać również electi. Jednak w konflikcie naśladowania powstaje - jak sądzi Girard - rywalizacja. Ona wymaga rozróżnienia, a rozróżnienie - przemocy. Zgodnie $z$ teologią, anioła wygnano z nieba i stał się diabłem (diabolos). Rozróżnienie, które wyjaśnia to wydarzenie, posiada quasi-feudalne tło. Jest to zwykle rozróżnienie dumy i szacunku, buntu i posłuszeństwa, egoizmu i służby, wyłączenia i włączenia. Za pomoca takiego rozróżnienia teologowie wyjaśniali upadek, skłonność ludzi do grzechu i tym samym pojawienie się rozróżnienia na dobre i złe, a zatem powstanie moralności. Wciąż chodzi jednak jedynie o to, by znaleźć się po dobrej stronie. Ta doktryna zapomniała o swoich źródłach i we wczesnej nowożytności stała się ponaglająca przestrogą, by mieć na uwadze zbawienie duszy i przestrzegać niezbędnych dla niego regư ${ }^{35}$.

To rozwiązanie pozostaje powiązane $z$ religia jako formą uzasadnienia, która ukrywa źródło obowiązywania rozróżnień. Jeśli religia nie jest

\footnotetext{
${ }^{34}$ Można podzielać zdanie Girarda, że w ten sposób ostatecznie przyjęto niewinność ofiary, czyli fikcję mitu. Jednakże zostaje jeszcze Judasz! Jest jedynym, o którym nie można powiedzieć, że nie wiedział, co czyni $(\lfloor k$ 23,24) i jedynym, który naprawdę próbował zbadać (obserwować), czy ten rzekomy Bóg naprawdę jest Bogiem i præęz to poniósł klęskę. Jest morderca, na którym wszystko się skupiło. Należałoby wyciagnąć wnioski i przyznać, że Jezus był jedynie wyeksponowaną ofiara, a Judasz był w rzeczywistości Chrystusem. Tak twierdzi Borges (1981: 215-221).

${ }^{35} \mathrm{~W}$ najprostszym przypadku dzieje się to również bez tego. Jezuici z Pekinu donoszą że co roku porzuca się około 20 do 30 tysięcy noworodków, zostawiając je na pewną śmierć. Zakon robi, co w jego mocy, jednak wskutek braku personelu może na czas ochrzcić około 3000 dzieci i w ten sposób je uratować. Zob. Noel (1780-1781: 160-183; 166 i nn.)
} 
w znacznej mierze zastępowana przez ekonomię, to przynajmniej przez nią marginalizowana, a mimetyczna rywalizacja (por. Dumouchel 1979, Anglietta 1984) wymknęła się kontroli, gdy nowożytne społeczeństwo ukazało się we własnych strukturach. Bank centralny byłby w każdym razie przeciążony tą funkcją. Mechanizm pieniądza wyzwala każdy rodzaj rywalizacji pragnienia (szkoccy filozofowie moralności próbowali pokazać, że za tym idzie seksualność) ${ }^{36}$, a zatem porządek może jedynie wynikać rekurencyjnie, a więc wyłącznie historycznie z każdorazowego rezultatu wyzwolonego działania komunikacji społecznej.

\section{/// 7.}

Jeśli założyć, że przejście od tradycyjnych formacji społecznych do nowożytnego społeczeństwa przyniosło ze sobą radykalne załamanie struktury i wykorzenienie wszystkich konwencjonalnych semantyk, nie można już więcej polegać na dawnych europejskich wytycznych - czy to na ontologii, czy etyce. Lecz nakaz: „Rozróżniaj!” pozostaje. Bez rozróżnień i określeń nic nie będzie funkcjonowało ani razu.

W nowoczesności życie oznacza orientowanie się w polikontekstualnym świecie, czyli akceptację rezygnacji z autorytatywnych wytycznych co do określonych rozróżnień i określeń. Nikt w społeczeństwie nie ma takiej pozycji, by móc z niej narzucić swoje rozróżnienie jako słuszne i obowiązujące. Innymi słowy, każde rozróżnienie, którego ktoś używa do obserwacji i opisywania, jest ze swej strony obserwowalne. Obserwując obserwatora, można zawsze zobaczyć, co on widzi za pomoca swojego rozróżnienia, a czego widzieć nie może - kiedy ktoś zdecyduje się go obserwować poprzez rozróżnienie na widoczne-dla-niego-ukryte-przednim. Nie każda codzienna komunikacja stawia tak złożone wymagania. Nasze społeczeństwo nie zostałoby poprawnie opisane, gdyby przemilczano istnienie tej możliwości - od czasów nowożytnej powieści, romantyzmu, Marksa, Freuda. Cybernetyka drugiego rzędu, cybernetyka obserwacji systemów obserwujących, jak dotąd oferuje najbardziej abstrakcyjne sformułowanie tego problemu (Foerster 1981, przekład niemiecki: Foerster 1985).

Łatwo wyjaśnić, że nie zmierza to wcale do samowoli i dowolności, do anything goes. Każde przypuszczenie o samowoli ma dla tego sposobu postrzegania jedynie przejściową jakość. Ponieważ dowolność nie istnieje empirycznie, samowolą nazywa się wyłącznie postawę: „obserwuj obserwatora, a rozpoznasz, że nie ma żadnej samowoli”. To sens nowożytnego pojęcia interesu. $Z$ tego powodu monarcha potrzebował doktryny

\footnotetext{
${ }^{36}$ Zob. na przykład Home (1788: 1 i nn). na temat rozwoju apogeum rycerskiego szacunku dla kobiet i jego upadku wraz ze wzrostem luksusu (,,a more substantial gallantry took place, not always, innocent" Home 1788: 87).
} 
suwerenności, a Marks teorii klas społecznych. Trzeba jedynie wiedzieć, czyje obserwacje człowiek może obserwować w różnych kontekstach i jakie rozróżnienia poczynić. Ujrzy wówczas, że zakładana samowola charakteryzuje się porządkiem zdeterminowanym struktura. Zaszczepienie nam strachu przed ,relatywizmem” było prawdopodobnie ostatnim podstępem diabła - ostatnim wysiłkiem w próbie ponownego przekroczenia monokontekstualnego obserwowania. W społeczeństwie bez elity i centrum stało się to bezsensowne ${ }^{37}$.

Wcale jednak nie dostrzeżono, w jaki sposób teologia daje sobie radę w świecie społecznym. Pytanie to ma wiele aspektów. Socjologicznie najpilniejszym do rozwiązania jest prawdopodobnie ten, że teologia obserwując siebie samą musi mieć świadomość, że wprawdzie tych, którzy ją obserwują, może w odpowiedzi obserwować ze schematem wierzący-niewierzący, ale nie jest w stanie adekwatnie pojąć, za pomoca jakich rozróżnień obserwuja ją inni (np. socjolodzy). Pod przewodnictwem teologii, samodzielnie decydującej o tym, jak chce obserwować obserwatora, system religijny stał się zamkniętym systemem, który dopóki działa, reprodukuje się przez własne rozróżnienia.

Gdy się to zaakceptuje, zawsze pozostaje pytanie, jaką technikę rozróżnienia dopuszcza teologia, by w podanych warunkach rozważyć religię. Stary problem, jak można obserwować Boga, jest niewatpliwie źle postawiony (tak było zawsze), ponieważ zmierza do paradoksu rozróżnienia tego, co nierozróżnione. Można jednak odzwierciedlać nakaz, który mówi, że musi dokonywać rozróżnień i że to, jakie rozróżnienie się zastosuje, ma swoje konsekwencje. Każde rozróżnienie, określone operacyjnie, stwarza różnicę. Jest ono tym i żadnym innym rozróżnieniem. Kiedy się je rozróżnia od innych rozróżnień (przykładowo moralność od korzyści), dla tego rozróżniania obowiązują te same zasady. Określiliśmy już klasyczne ujęcie problemu: konieczność wolności. Można by również powiedzieć, że odpowiedzialność leży w samym wyborze rozróżniania, na przykład w moralizowaniu czy w poszukiwaniu racjonalności. Żaden fanatyzm form rozróżniania nie może powoływać się na naturę, ale także i na Boga, aby zdjać z siebie ciężar (tego wyboru).

Jest możliwe, że należy to pojmować jako nakaz Boga i akceptować nieuchronność samodzielności. W kontekście chrześcijaństwa ten krok nie byłby na tyle duży, by widzieć w nim wolność dawaną z miłością.

Tak określany Bóg nie kalkuluje. Nie potrzebuje form.

Kto zawsze kalkuluje, postępuje zgodnie z nakazami, które z kolei przedstawia i wyjaśnia kalkulacja Spencera Browna. Jeśli ktoś tak postępuje,

${ }^{37} \mathrm{~W}$ odniesieniu do tego por. interpretację totalitaryzmu M. Gauchet (1976: 3-28). 
może kalkulować, jeśli zaś nie - to nie. Nie potrzebuje autora, dalszej podstawy czy Boga. Może wystarczyć mu konieczność sekwencji działań, kiedy chce coś osiagnać, a logika upewni go, że każdy, kto tak postępuje, dojdzie do analogicznych rezultatów. Tylko w ten sposób nie można wykluczyć pytania o różnicę, która powstaje, kiedy człowiek postępuje w ten sposób, a dalej - pytania o „motywy” (jak to się zdradliwie nazywa u Spencera Browna) każdej oceny rozróżniania w odróżnieniu od innej. Jedyną odpowiedzia na to pytanie jest w naszej tradycji wskazanie na Boga.

Przełożyła Kinga Marulewska Przekład przejrzał Marek M. Kurowski

/// Die Weisung Gottes als Form der Freiheit, w: Soziologische Aufklärung, Band 5, s. 75-88 C 1990 VS Verlag, Wiesbaden 1990.

Bibliografia:

/// Anglietta, M. i Orléan, A. 1984. La violence de la monnaie. Paris: PUF. /// Awn, P. 1983. Satan's Tragedy and Redemption: Iblis in Sufi Psychology. Leiden: E.J. Brill.

/// Borges, J. 1981. Drei Fassungen von Judas. W: Gesammelte Werke. Eržählungen 1. München: Hanser.

/// Burton Russel, J. 1984. Lucifer: The Devil in the Middle Ages. Ithaca: Cornell University Press.

/// Dumouchel, P. i Dupuy J.-P. 1979. L'enfer des choses: René Girard et la logique de l'économie. Paris: Seuil.

/// Eriugena, Jan Szkot. 1968. Periphyseon (De divisione naturae), t. I. Sheldon -Williams, I.P. (red.). Dublin: Dublin Institute for Advanced Studies. /// Eriugena, Jan Szkot. 1972. Periphyseon (De divisione naturae), t. II. Sheldon -Williams, I.P. (red.). Dublin: Dublin Institute for Advanced Studies. /// Eriugena, Jan Szkot. 2009. Periphyseon (De divisione naturae) Ks. 1. Przeł. Kijewska, A. Kęty: Antyk.

/// Foerster von, H. 1981. Observing Systems. Seaside Cal.: Intersystems Publications.

/// Foerster von, H. 1985. Sicht und Einsicht: Versuche zu einer operativen Erkenntnistheorie. Brauschweig: Friedrich Vieweg und Sohn.

/// Gauchet, M. 1976. L'experience totalitaire et la pensée de la politique. „Esprit” Juli/August: 3-28.

/// Gese, H. 1977. Zur biblischen Theologie: Alttestamentliche Vorträge. München: Kaiser.

/// Girard, R. 1972. La violence et le sacré. Paris: Grasset. 
/// Girard, R. 1978. Des choses cachées depuis la fondation du monde. Paris: Grasset.

/// Girard, R. 1982. Le bouc émissaire. Paris: Grasset.

/// Girard, R. 1983. Rzeczy ukryte od zatożenia świata. Przeł. Goszczyńska, M. „Literatura na świecie” 12: 74-182.

/// Girard, R. 1987. Koziot ofiarny. Przeł. Goszczyńska, M. Lódź: Wydawnictwo Lódzkie.

/// Girard, R. 1993. Sacrum iprzemoc. Przeł. Plecińscy, M. i J. Poznań: Brama. /// Glanville, R. 1979. Beyond the Boundaries. W: Ericson, R.F. (red.). Improving the Human Condition: Quality and Stability in Social Systems. Washington: SGSR. /// Glanville, R. i Varela F. 1981. „Your Inside is Out and Outside is In” (Beatles 1968). W: Lasker, G. E. (red.). Applied Systems and Cybernetics, t. II. New York: Pergamon Press.

/// Glanville, R. 1988. Objekte. Przeł. Baecker, D. Berlin: Merve Verlag. /// Günther, G. 1979. Life als Polycontexturality. W: Beiträge zur Grundlegung einer operationsfähigen Dialektik. t. II. Hamburg: Meiner.

/// Home,H.(LordKames) 1788.Sketches of theHistory of Man.t.II.Edinburgh. /// Janowski, B. 1982. Sübne als Heilsgeschehen: Studien zur Sühnetheologie der Priesterschrift und zur Wurzel KPR im Alten Orient und im Alten Testament. Neukirschen: Neukirchener Verlag.

/// Jung, L. 1925. Fallen Angels in Jewish, Christian and Mobammedan Literature: A Study in Comparative Folklore. „The Jewish Quaterly Review” 15: 467-502. 1926, 16: 45-88, 171-205, 287-336.

/// Luhmann, N. 1989. Die Ausdifferenzierung der Religion. W: Gesselschftsstruktur und Semantik, t. III. Frankfurt/Main: Suhrkamp, s. 259-357.

/// Luhmann, N. 1990. Indentität - was oder wie?. W: Soziologische Aufklärung, t. V. Konstruktivistische Perspektiven. Opladen: Westdeutscher Verlag, s. 15-30. /// Lyotard, J.-F. 1979. La condition postmoderne: Rapport sur le savoir. Paris: Les Éditions de Minuit.

/// Lyotard, J.-F. 1983. Le Différend. Paris: Les Éditions de Minuit.

/// Lyotard, J.-F. 1997. Kondycja ponowoczesna: raport o stanie wiedzy. Przeł. Kowalska, M., Migasiński, J. Warszawa: Aletheia.

/// Marconville de, J. 1564. De la bonté et mauvaistié des femmes. Paris.

/// Mikołaj z Kuzy. 1964a. De venatione sapientie. W: Gabriel, L. (red.). Philosophisch-theologische Schriften, t. I. Wien: Herder.

/// Mikołaj z Kuzy. 1964b. De docta ignorantia. W: Gabriel, L. (red.). Philosophisch-theologische Schriften, t. I. Wien: Herder.

/// Mikołaj z Kuzy. 1966. De non-aliud. W: Gabriel, L. (red.). Pbilosophischtheologische Schriften, t. II. Wien: Herder.

/// Mikołaj z Kuzy. 1997. O oświeconej niewiedsy. Przeł. Kania, I. Kraków: Znak. 
/// Noel, P.F. 1780-81. Mémoire sul l'état des Missions de la Chine... (1703). W: Lettres édifiantes et curieuses, écrites des missions étrangères. Paris: Chez J.G. Merigot.

/// Reynolds, E. 1971. A Treatise of the Passions and Faculties of the Soule of Man (1640). Gainesville, Fla.: Scholars; Facsimiles \& Reprints.

/// Rumi, J. 1925-1940. Mathnawi-i ma'nawi, t. VI. Nicholson, R.A. (red.). London: Luzac.

/// Rumi, J. 1926. Mathnawi-i ma'nawi, t. III. Nicholson, R.A. (red.). London: Luzac.

/// Smullyan, R. 1977. The Tao is silent. New York: Harper \& Row. /// Spangenberg, P.-M. 1987. Maria ist immer und überall: Die Alltagswelten des spätmittelalterlichen Mirakels. Frankfurt: Suhrkamp.

/// Spencer Brown, G. 1979. Laws of Form. New York: E.P. Dutton. /// Twain, M. 1962. Letters from the Earth. New York: Harper \& Row. /// Twain, M. 1966. Listy z ziemi. Przeł. Kydryński, J. Warszawa: Książka i Wiedza.

/// Valéry, P. 1960. Histoires brisées. W: Tegoż. CEuvres, t. II. Paris: Gallimard. /// Varela, F. 1975. A calculus for self-reference. „International Journal of General Systems" 2: 5-24.

/// Zwemer, S. 1937. The Worship of Adam by Angels (with Reference to Hebrews 1:6). „The Moslem World” 27: 115-127. 